\title{
What Factors Determine the Rate and Level of Improve Coffee Variety Adoption Under Smallholder Farmers in North Western Ethiopia?
}

\author{
Welay Tesfay Tewelemedhin \\ Ethiopia Institute of Agriculture Research, EIAR \\ Pawe Agricultural Research Center, P.o.Box 25, Pawe, Ethiopia
}

\begin{abstract}
Ethiopia is the origin of Arabica coffee and played plenty role on breeding, promotion, multiplication and disseminating of Arabica coffee plant to coffee producers and it becomes main source of income and foreign currency to Ethiopian economy. Despite its importance, little is known about the factors that determine the rate and level of improved coffee adoption to boost the coffee production. Therefore, this research aimed to investigate the factors that determine the rate and level of improve coffee varieties adoption under smallholder farmers in North Western Ethiopia. Total 114 sample households (34 Improved and 80 local coffee producers) were taken through systematic and random sampling method. Descriptive and Tobit model were adopted to analyze the data. The descriptive statistics result showed that Adopters of improved coffee varieties were owned larger land, allocated larger land for coffee, holds larger animals in TLU, produced higher coffee output, earned higher income of coffee, more accessed to extension and financial services, taken more training on new coffee and other crop varieties and more educated than non-adopters whereas non-adopters were had larger family size, adult equivalent and man equivalent than their counterparts. It also showed that $29.82 \%$ and $40.46 \%$ of adoption rate and level of improve coffee varieties adoption was reached in terms of respondent response and area coverage respectively. Tobit model result indicated that sex of household head, educational status of household head, participation on demonstration, area allocated for coffee production, income earned from coffee and access to agricultural extension service was the main factors determined the improve coffee varieties adoption rate and levels. This research suggests that expanding education, support demonstration activities and address agricultural extension services to all smallholder farmers that improved the improved coffee variety adoption as well as income and food security status of smallholder farmers. Therefore, governmental authorities and NGOs should be focused on the expanding of education and agricultural extension services to all smallholder coffee producers to improve coffee varieties adoption, source of income and ensure food security at household level in the coffee pro agro-ecologies of the countries.
\end{abstract}

Keywords: Coffee, Adoption rate, adoption level, Improve coffee variety and Tobit model

DOI: $10.7176 / J P I D / 59-04$

Publication date: February $28^{\text {th }} 2021$

\section{Introduction}

Coffee (Coffea arabica), is perennial crop grown in tropical and subtropical of the world's agroecology and most exported perennial crop. Arabica coffee is the dominant worlds coffee production which covers $70 \%$ global coffee production and the rest is Robusta coffee (Fantaye, 2019). Ethiopia is the origin of Arabica coffee and played plenty role on breeding, promotion and disseminating of Arabica coffee plant to the world. It produced only Arabica coffee and contributed big role on breeding, promotion and multiplication of it over the rest of world's beneficiaries and it is superior over Robusta coffee due to its fine aroma, stronger body and pleasant acidity (Zewdu, 2016). During 2017/2018 cropping season, there were five million smallholder coffee producers that cover seven hundred twenty five thousand hectare of land and produced 4.4 Million Quintal of coffee with $6.19 \mathrm{Qt} / \mathrm{ha}$ productivity (CSA, 2018). It is the main export commodity crop and source of foreign currency to Ethiopian Gross Domestic Product(GDP) which covers 25\% the total export (Misganaw, 2015) and (Samuel, 2016).

Benshagul Gumuz is one of 9 regional states of the country's which is produced coffee during the same cropping season. The productivity of coffee was $3.89 \mathrm{Qt} / \mathrm{ha}$ which was lower than the national coffee productivity (CSA, 2018). Wombera district is one of the Benshangul Gumuz districts which produced coffee. Its quality is well known as Wombera coffee by the Metekel zone and North West part of the country. It traded under wollega coffee in Gimbi Market center of Ethiopia Commodity Exchange (EXC). However, due to its High demand around Metekel zone and North Western part of the country, it also traded on black market around these areas. As result, coffee production in the district was increased from year to year. The coffee production trend in the district showed an increasing trend both in production and area planted under coffee. Since 2010 the district has been produced 6215 Qt of coffee from 1126 ha but now it reached 16,965 Qt amount of coffee from3393 ha of land (WDAO, 2018). In the district, coffee is base of the small holders' livelihoods and become main source of their income. Thus, the agriculture office has been given primary priority on the enhancement of coffee production and 
productivity through establishment of coffee nursery site, preparation of improved coffee variety seedlings and dissemination of these seedlings to the coffee producers'. In addition to this, a smallholder farmer also brings different improved coffee varieties from neighbor Zone like Wollega and Asosa Zone(WDAO, 2018). Despite these tremendous efforts, the factors that determine the rate and level of improved coffee variety adoption are not well known in the district. Therefore, it is essential to determine the factors affecting the rate and level of improve coffee varieties adoption. The result of the paper is important to boost the coffee production at national level as well to generate more foreign currency to the country. It is also important to targeted agricultural extension activities, evidence based decision and policy options for increasing coffee production under smallholder farmers. Then this paper is intended to fill the knowledge gap of improve coffee varieties adoption determinants under smallholder farmers. Therefore, this research was focused on factors determining improve coffee varieties adoption rate and adoption level under smallholder farmers in North Western Ethiopia.

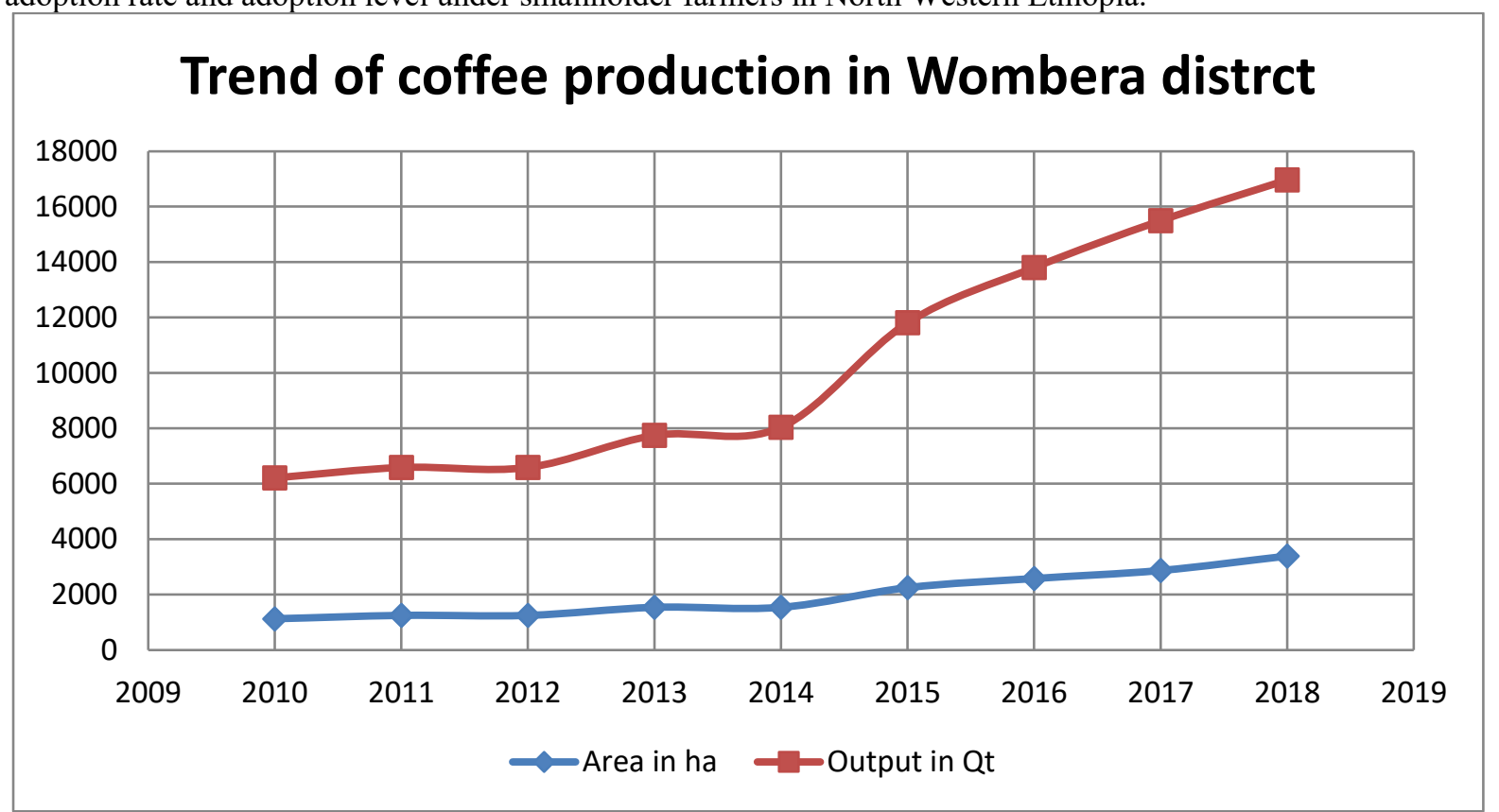

Figure 1 Trend of coffee production in Wombera district

\section{Methodology}

\subsection{Description the study Areas}

The study conducted in Wombera district, Metekel Zone, Benshangul Gumuz National Regional state, North West of Ethiopia as indicated in fig 2 with an area coverage of 736,425 hectare of land and population 97,152(48,479 male) inhabitants (WAO, 2018). The district located $654 \mathrm{~km}$ far away from Addis Ababa to North West direction with geographically location of $10^{0} 35^{\prime} 12.53$ ' ' latitude $35^{\circ} 47^{\prime} 33.27^{\prime \prime}$ longitude(WDAO, 2018).

The district altitude ranges from 600 to 2731 masl and bounded in the West by Guba and Dangur districts, East by Kemashi Zone, by North by Bullen district and South by Asosa and Kemashi Zone. Its farming system is characterized by mixed farming and coffee planting agro-forestry practices. The district is among the coffee growing district of Benshangul Gumuz districts. It has ten coffee growing Kebele with area coverage of 3393 hectare of land out of twenty Kebeles(WDAO, 2018). 


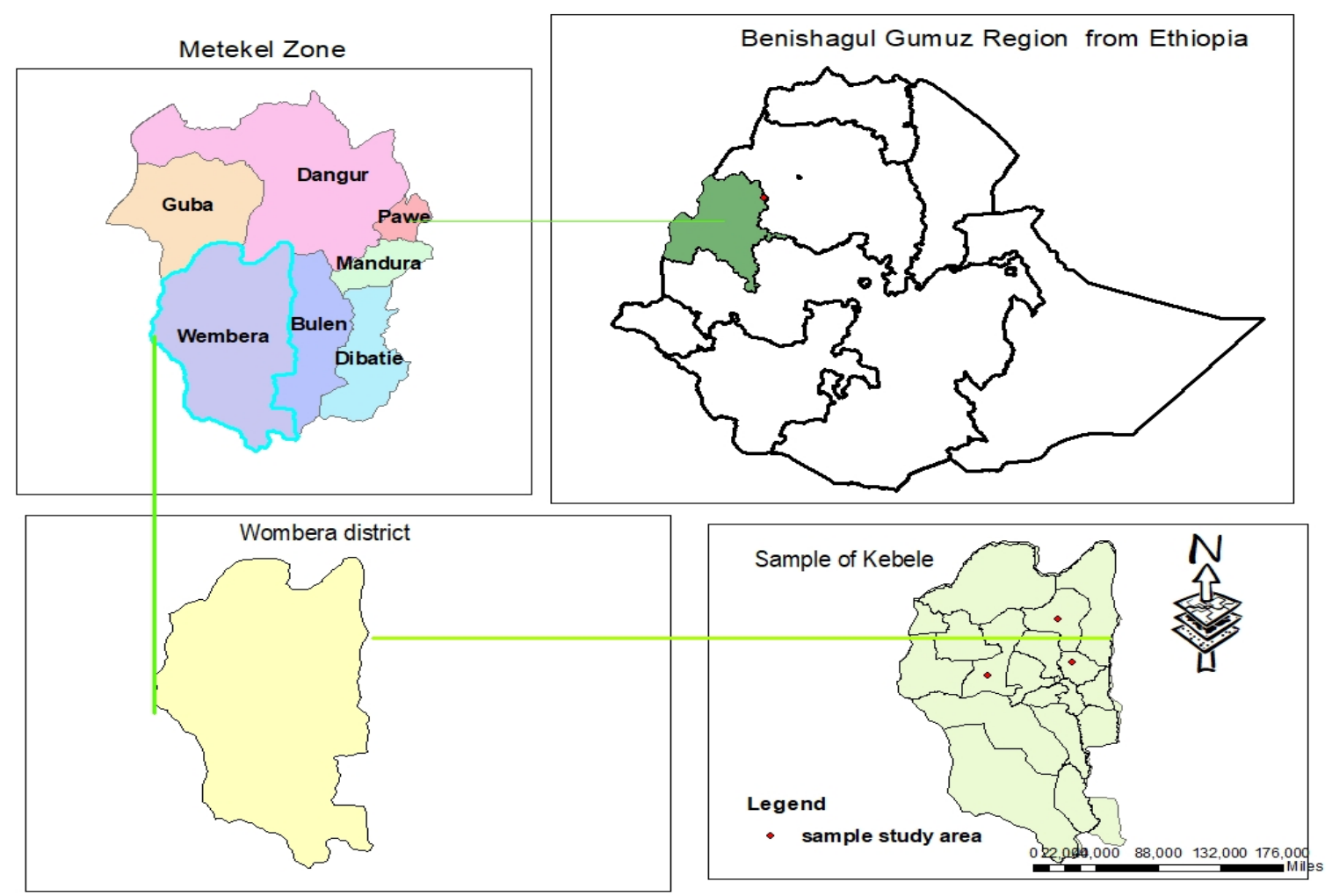

Figure 2 Map of Study Area

\subsection{Method of sampling Design and Sample Size}

Wombera district has ten coffee grower Keble's out of twenty administrative Keble's. These Keble's were characterized as high, medium and low coffee grower in the study area. Base on the potential of coffee growers in terms of area and coffee production these Keble's' clustered in to three categories which are high, medium and low coffee producers. One Keble from each cluster was selected using simple random sampling technique. Based on this Bolelie, Mensibu and Sanki Keble were selected from the potential, medium and low coffee growing Keble's respectively. Sample unit were selected using systematic random sampling technique (SRS) with probability proportion to sample size. Accordingly 114 Smallholder coffee producers were selected from three targeted Keble for this study.

In designing survey, the determination of appropriate sample size is paramount importance for inference of the findings based on the sample population. To determine the size of sample, this study adopted the following formula developed by (Yemane, 1967) as he assumed $p=0.05$ that most variability of the population would be covered

$$
\mathrm{n}=\frac{\mathrm{N}}{1+\mathrm{N}(\mathrm{e})^{2}}
$$

Where: $\mathrm{n}=$ statistically acceptable sample size

$$
\mathrm{N}=\text { Total size of target population }
$$

$\mathrm{e}=$ level of precision (error level) at 95\%, confidence level (0.05).

Accordingly 114 sample households were taken from three Keble coffee producers.

Table 1Sample of smallholder Coffee producers by Keble

\begin{tabular}{|c|c|c|c|c|}
\hline \multirow{3}{*}{ Wombera } & Bolelie & 450 & 40 & 35.10 \\
\hline & Mensibu & 380 & 37 & 32.45 \\
\hline & Sanki & 340 & 37 & 32.45 \\
\hline
\end{tabular}

$$
\text { District Keble Total coffee producers \# of sample unit selected Share of sample }
$$

Source: Survey data (2018)

\subsection{Methods of data analysis}

\subsubsection{Descriptive Statistics}

Descriptive statistics like mean, standard deviation and frequency were widely employed to describe the socio economic and institutional characteristics of sample households in study area. 


\subsection{Econometric model analysis}

\subsubsection{Definition and rate of improved coffee variety Adoption}

Adoption is a decision to use of improved variety as the best course of action available. The decision to adopt improved coffee variety, involves a process composed of learning, deciding, and acting over a period of time. The way in which an individual adopts an improved new variety is involves the following five steps namely, awareness stage, interest stage, evaluation stage, trial stage and adoption stage (Kedir et al., 2017). In this case, smallholder farmers who used and cultivated improved coffee variety in the last ten years considered as adopters. Smallholder farmers who is not used and cultivated coffee variety for the last ten years considered as non-adopters or local coffee producers. The rate of improved coffee variety adoption was the percentage of improved coffee variety sown out of the total sample taken while its level of adoption was share of area coverage by improved coffee variety out of the total sown coffee area.

The adoptions of improved coffee variety were analyzed using the Tobit model. It is more appropriate to measure the probability of adoption and level of coffee variety use. Tobit model is more advantageous over Probit model when the dependent variables are binary and continuous characteristics. Mathematically, it expressed as follow

$$
Y i=\beta i+X i+U i-------------2
$$

Where $\mathrm{Yi}=$ the observed dependent variable, in this the area under improved coffee variety

$\mathrm{Xi}=$ explanatory variables

$\beta \mathrm{i}=$ parameters to be estimated

$\mathrm{Ui}=$ is an error term

The parameter of the model was estimated using the maximum likelihood method. Similarly (Tobin, 1958), the expected value of adoption and level of improved coffee variety adoption across all observation were estimated

$$
E(Y)=X \beta F(z)+\delta f(z)-------------3
$$

Where $\mathrm{z}=\mathrm{X} \beta / \sigma, \mathrm{F}(\mathrm{z})$ is the cumulative distribution function, $\mathrm{f}(\mathrm{z})$ is the value of derivative of the normal curve at a given point, $Z$ is the value of $Z$ - scores for the area under normal curve, $\beta$ is the vector of Tobit maximum likelihood and $\sigma$ is the standard error of the error term. As (Maddala, 1986) justified, the marginal effects of the explanatory variables on the expected value of dependent variables is estimated as follow

$$
\frac{\partial E(Y i)}{\partial \boldsymbol{X} \boldsymbol{i}}=F(z) \beta i------------4
$$

And the change in probability of area under improved coffee variety as the explanatory variables change is calculated as

$$
\frac{\partial F(z)}{\partial X i}=\frac{f(z) \beta i}{\sigma}---------------5
$$

Also the change in the level of adoption with respect to a change of explanatory variables among variety adopters is estimated as

$$
\frac{\partial E\left(\frac{Y i}{Y} *>0\right)}{\partial X i}=\beta\left[1-\frac{z f(z)}{F(z)}-\left[\frac{f(z)}{F(z)}\right]\right]---------6
$$

\subsection{Definition of variables and its measurement used in the Model}

Cultivation of perennial crops including coffee influences different factors to enhance its production and productivity. Planting coffee has its own opportunity cost that could be hindered or promoted to expand or decrease cultivation of coffee crops due to running of any business has its own opportunity costs. Hence, determining the factors that influence the rate and level of coffee improve coffee variety adoption, strengthen the factors positively influenced it and take corrective measure to negatively influenced it could courage the smallholder coffee producers to produce more and improved the income earned from coffee cultivation. Therefore, this research focused on the determinants of improves coffee varieties adoption rate and levels under smallholder farmers in North Western Ethiopia. The definition and its measurements of the variables that included in the model was hypothesized to influence improve coffee variety adoption and their expected effects are described as follows. 
Table 2 Definition of variables and measurement used in the model

\begin{tabular}{lll}
\hline Covariates & Measurement & Expected Sign \\
\hline HH sex & Dummy, Yes/No & - \\
HH Age & Continuous, years of old & + \\
HH Edu & continuous, completed class in year & + \\
Model farmer & Dummy, Yes/No & + \\
Social contact & Dummy, Yes/No & + \\
Own land & Continuous, own land in ha & + \\
Access to save & Dummy, Yes/No & + \\
Training on coffee & Dummy, Yes/No & + \\
Participation on Demo & Dummy, Yes/No & + \\
Coffee area & Allocated land for coffee & + \\
Coffee income & Continuous, income earns from coffee & - \\
Other area & allocated land for other crops & + \\
Fertility & discrete, state its fertility & - \\
Slope & Discrete, state its slope & + \\
Access to extension & Dummy, Yes/No & + \\
\# of extension contact & Continuous, \# contact per year &
\end{tabular}

\section{Result and Discussion}

\subsection{Descriptive statistics}

Descriptive statistics were employed to describe the socio economic and institutional characteristics of sample households in study area. The descriptive statistics results revealed that adopter households were statistically significance and/or holds more than non-adopter groups in livestock holding in TLU, complete higher class, owned land, cultivated land allocated for coffee, amount of coffee output produced and income generated from it. On the contrary non-adopter are different and acquire more than adopters in adult equivalent, man equivalent, family size and most of them owned radio(Table 3 and 4).

\subsection{Demographic and socio economic characteristics of sampled households'}

Majority of the sample households were male head (92.11\%) and 7.89\% of them were female headed households. Out of these $24.56 \%$ and $5.26 \%$ were male and female household headed that adopted improved coffee variety respectively. The result of chi $^{2}$ statistics revealed that sex of household has positive and significance effect on adoption of improved coffee varieties at $1 \%$ significance level. This is due to male head households are more social contact and did not occupied with family care activities which create an opportunity to participate in different meeting and training that facilitated to adopt new technologies. The average ages of adopters (44 years old) are slightly greater than the non-adopters (42.41 years old) of improved coffee varieties with no statistical significance between them. Family size, adult equivalent and man equivalents are one of the demographic variables that investigated to analysis its effect of the adoption of improved coffee varieties. Even if the non-adopters have slightly more family size, adult equivalent and man equivalent there is no statically significance and effect on the adoption of improved coffee varieties. The findings are similar with(Fitsum, 2016) and (WelayTesfay, 2019)

Education has an ability to sharpen managerial knowledge and skills that leads to decide good decisions in farming activities. Education of the household head has a positive and significant effect on adoption improved coffee varieties at $5 \%$ level of significance, indicating that better educated household head can understand agricultural instructions easily, have better access to information, eager to apply new technology as well as have higher tendency to adopt improved agricultural technologies and able to apply technical skills than uneducated ones. Adopters of improved coffee varieties were completed higher class (9.59) than non-adopters (3.19) and helped to wide their skills and knowledges about the importance and production of improved coffee varieties. Adopters are allocated larger cultivated land for coffee than counterpart and produced more coffee output as well as earned more revenue from sell of coffee output. Area allocated for coffee, coffee output and income earned from coffees have positive and significance effect on the adoption of improved coffee varieties at $1 \%$ of significance level in North Western Ethiopia. It is obvious that more cultivated land allocated for coffee has positive effect that enhanced the coffee output as well as income earned from the coffee sector at household and country level. the findings is similar with (Regasa Dibaba et al., 2018; Welay and Desalegn, 2019) 
Table 3 Demographic and socio-economic characteristics of sample households

\begin{tabular}{ccccc}
\hline $\begin{array}{c}\text { Demographic and Scio-economic } \\
\text { factors }\end{array}$ & Adopter & Non-Adopter & Total & $\begin{array}{c}\text { Chi } \\
\text { test value }\end{array}$ \\
\hline Sex & 28 & 77 & 105 & $\mathbf{6 . 3 4}$ \\
Male & 6 & 3 & 9 & \\
Female & 44 & 42.41 & 42.89 & 0.84 \\
Age & 6.47 & 7.03 & 6.86 & 1.43 \\
Family size & 5.22 & 5.53 & 5.44 & 0.94 \\
Adult equivalent & 3.89 & 3.95 & 3.93 & 0.17 \\
Man equivalent & 9.45 & 8.20 & 8.57 & 1.63 \\
TLU & $\mathbf{9 . 5 9}$ & $\mathbf{3 . 1 9}$ & $\mathbf{5 . 1 0}$ & $\mathbf{2 . 4 3}$ \\
Education & 3.71 & 3.27 & 3.40 & -1.13 \\
Own land & $\mathbf{2 . 2 3}$ & $\mathbf{1 . 3 8}$ & $\mathbf{1 . 6 3}$ & $\mathbf{2 . 9 9 ^ { * * * }}$ \\
Coffee area & $\mathbf{7 3 8 . 8 2}$ & $\mathbf{4 3 0 . 5 6}$ & $\mathbf{5 2 2 . 5 0}$ & $\mathbf{3 . 4 4} * * *$ \\
Coffee output & $\mathbf{3 7 , 2 0 2 . 9 4}$ & $\mathbf{2 1 , 8 6 8 . 1 7}$ & $\mathbf{2 6 , 4 4 1 . 7 0}$ & $\mathbf{3 . 6 7}$ \\
Coffee income & & & & 1.46 \\
Model farmer & 16 & 28 & 44 & \\
Yes & 18 & 52 & 70 & \\
No & & & & \\
Own radio & 27 & 60 & 87 & \\
Yes & 7 & 20 & 27 & \\
No & & &
\end{tabular}

Source: Survey data (2018)

$*, * *, * * *$ Statistical Significance level at 10,5 and $1 \%$ respectively

\subsection{Social and Institutional characteristics of sampled households'}

The social variables like member of community leadership, member of organization and participate on demonstration have no statistically significance between adopters and non-adopters of improved coffee varieties. Even if these social variables have no statistical difference and effect on the adoption of improved coffee varieties, $18.42 \%$ of adopter and $25.44 \%$ of non-adopters, $13.16 \%$ of adopter and $37.72 \%$ of non-adopters, $4.39 \%$ of adopter and $4.39 \%$ of non-adopters are member of community leadership, member of organization and participate on demonstration respectively during the survey period in North western Ethiopia whereas Social network of sample households have positive and significance effect on the decision to adopt new coffee varieties. $29.83 \%(22.81 \%$ adopter and $7.02 \%$ non-adopter) of the total sample households have social network which in turn has positive effect on the decision to adopt new coffee varieties. The result of $\mathrm{chi}^{2}$ indicated that social network has positive and significance effect to adopt new coffee varieties at 5\% significance level which helped to access to financial service, cooperative services which encouraged adopting improved agricultural improved technologies in general and coffee varieties in particular. The findings are similar with (Diro et al., 2017; Dibaba and Goshu, 2018; Welay and Desalegn, 2019)

Access to financial service, extension contact, trained on new coffee varieties and other new crop varieties productions are among the institutional variables that have positive and significance effect on the decision to adopt improved coffee varieties between adopter and non-adopters. According to the survey data almost $50 \%(16.67 \%$ adopter and $27.19 \%$ non-adopter) of the sample households were access to financial service and trained on new coffee varieties production which is moderately covered on accessing financial service and training activities on new coffee varieties production. Furthermore more than $60 \%$ ( $21.93 \%$ adopter \& $38.60 \%$ non-adopter) and $80 \%$ ( $28.07 \%$ adopter \& $52.63 \%$ non-adopters) of the sample households were trained on other new crop varieties production and addressed extension service respectively. $\mathrm{Chi}^{2}$ statics result showed that both access to financial service and trained on new coffee varieties production have positive and significance effect on decision to adopt new coffee varieties at $10 \%$ significance level while extension contact and trained on other new crop varieties production have positive and significance effect on decision to adopt new coffee varieties at $5 \%$ significance level. The findings are similar with(Moti et al., 2013; Kedir et al., 2017; Welay and Desalegn, 2019; WelayTesfay, 2019) 
Table 4 Social and institutional characteristics of sampled households

\begin{tabular}{|c|c|c|c|c|}
\hline social and institutional factors & Adopter & $\begin{array}{l}\text { Non- } \\
\text { Adopter }\end{array}$ & Total & Chi ${ }^{2}$ or T-test value \\
\hline Member of community leadership & & & & 0.04 \\
\hline Yes & 21 & 29 & 42 & \\
\hline No & 13 & 51 & 72 & \\
\hline Member of organization & & & & 0.89 \\
\hline Yes & 15 & 43 & 58 & \\
\hline No & 19 & 37 & 56 & \\
\hline Social network & & & & $3.62 * *$ \\
\hline Yes & 26 & 8 & 34 & \\
\hline No & 8 & 72 & 80 & \\
\hline Participation on Demo & & & & 2.13 \\
\hline Yes & 5 & 5 & 10 & \\
\hline No & 29 & 75 & 104 & \\
\hline Access to financial service & & & & 2.84* \\
\hline Yes & 19 & 31 & 50 & \\
\hline No & 15 & 49 & 64 & \\
\hline Extension contact & & & & $5.60 * *$ \\
\hline Yes & 32 & 60 & 92 & \\
\hline No & 2 & 20 & 22 & \\
\hline Train on new coffee variety & & & & 2.84* \\
\hline Yes & 19 & 31 & 50 & \\
\hline No & 15 & 49 & 64 & \\
\hline Train on new other crops & & & & $3.43 * *$ \\
\hline Yes & 25 & 44 & 69 & \\
\hline No & 9 & 36 & 45 & \\
\hline
\end{tabular}

Source: Survey data (2018)

$*, * *, * * *$ Statistical Significance level at 10,5 and $1 \%$ respectively

\subsection{Improved coffee variety adoption rate and level in North Western Ethiopia}

Wombera district is one of potential coffee grower in Benshangul Gumuz region which its coffee has special taste, preference and demand by the coffee end users. Wombera coffee is traded under regulated rule and laws in Ethiopia commodity exchange (EXC) as coffee product. Even if wombera coffee is traded under wollega coffee in Gimbi Market center of EXC, it also traded in black market due to higher demand and shortage of supply relative to its demand in Debrezeit town, the capital city of wombera district. In response of these demands the district smallholder coffee producers were adopted different improved coffee varieties to enhance their coffee production and productivity during the last ten years. The adoption rate of improve coffee variety is the percentage of improve coffee variety planted out of the total sample taken while its level of adoption is share of area coverage by improve coffee variety out of the total planted coffee areas. The adoption rate of improve coffee variety is larger in Bolelie Keble (14.91\%) than Menesibu Keble (8.77\%) and Sanki Keble (6.14\%). On average 29.82\% of the sample household head responses were Adopters (they were says "I used improve coffee variety") whereas the rest $70.18 \%$ responses were non adopters. The adoption level of improve coffee varieties is also larger in Bolelie Keble $(25.24 \%)$ than Menesibu Keble (11.40\%) and Sanki Keble (4.03\%). The level of improve coffee variety adoption is $40.69 \%$ which is the area covered by improve coffee varieties ( 75.75 hectare) out of the total area planted under coffee (186.25 hectare. The chi ${ }^{2}$ test showed that there is statistically significance between the three Keble's in terms of adoption rate and level of improve coffee varieties (Table 5). This is due to the high contact with development agents and agricultural experts and Bolelie Keble is nearest than Menesibu and Sanki Keble to Development Agent office. Near distance to Development Agent office affects positively to adopt improve coffee variety the finding similar with (Diro et al., 2017; Kedir et al., 2017; WelayTesfay, 2019) 
Table 5 Improve coffee varieties rate and level of adoption in North Western Ethiopia

\begin{tabular}{|c|c|c|c|c|}
\hline \multirow[t]{2}{*}{ Keble } & \multicolumn{2}{|c|}{ Rate of improve coffee varieties adoption } & \multirow[t]{2}{*}{$\%$ Adopter } & \multirow[t]{2}{*}{$\%$ Non-Adopter } \\
\hline & Adopter & Non Adopter & & \\
\hline Bolelie & 17 & 23 & 14.91 & 20.18 \\
\hline Menesibu & 10 & 27 & 8.77 & 23.68 \\
\hline Sanki & 7 & 30 & 6.14 & 26.32 \\
\hline Total & 34 & 80 & 29.82 & 70.18 \\
\hline \multicolumn{5}{|c|}{ Level of improve coffee varieties adoption } \\
\hline Bolelie & 47 & 42.25 & 25.24 & 22.69 \\
\hline Menesibu & 21.25 & 29.5 & 11.40 & 15.84 \\
\hline Sanki & 7.5 & 38.75 & 4.03 & 20.81 \\
\hline Total & 75.75 & 110.5 & 40.67 & 59.33 \\
\hline
\end{tabular}

Source: Survey data (2018)

Improve coffee producers by Keble Pearson $\mathrm{chi}^{2}(2)=5.31 \quad \mathrm{PR}=0.07$

\subsection{Adoption rate of improve coffee varieties in North Western Ethiopia}

According the survey, sample households were started planting of coffee trees since 1970s in Wombera district. In the first time, they were gained their seedling and / or seeds from their relatives and friends within the district and outside the district west wellega zone Oromia reginal state and Kemashi and Assosa Zones of Benshangul Gumuz regional states. Sample households were planted different improved and local coffee varieties during the last ten years in the district. 741(1.75\%) and Koti (85257)(6.14\%) are among the improved coffee varieties and Kubru(37.72\%), Mito(19.30\%) and Bedesa(13.16\%) are among the local coffees preferred and planted by sample households. However, $21.93 \%$ of the improved coffee variety adopters are not knows clearly the varieties that they were planted (Table 6). The result similar with(Moti et al., 2013) stated that $9.7 \%$ of the respondent did not know any improved maize varieties

Table 6 Types of improve and local varieties planted by sample household in wombera district Improved coffee varieties

$$
741
$$

$\operatorname{Koti}(85257)$

Improved but I did not know

Kubru(local)

Mito(local)

Bedesa(local)

Total Frequency

2

7

25

43

22

15

114
Percent

1.75

6.14

21.93

37.72

19.30

13.16

100

\section{Source: Survey data (2018)}

\subsection{Source of coffee seed or seedling of sample households in North Western Ethiopia}

The district agricultural office has been established coffee nursery sites and extensively prepared and disseminated different coffee varieties to the end users during the last two decades. As a result district agricultural office is the main actor on preparation, searching and disseminating of coffee seedlings. $61.4 \%$ sample households were gained their seedling from other sources like family, NGOs, farmer to farmer exchange, local seedling producers while $38.6 \%$ of them were used their own saved seed (Table 5). Unlike (Misganaw, 2015), district agriculture office role on supplying of improved coffee varieties is lower(13.2\%) in this paper.

Table 7 Source of coffee variety seedling and/or seed

\begin{tabular}{ccc} 
Source of coffee seedling or seed & Frequency & Percent \\
\hline Own saved seed & 44 & 38.6 \\
District Agriculture Office & 15 & 13.2 \\
Gift from family/neighbor & 23 & 20.2 \\
Farmer to farmer seed exchange & 8 & 7.0 \\
Local seedling producers & 13 & 11.4 \\
Provided free by NGOs & 11 & 9.6 \\
Total & 114 & 100.0
\end{tabular}

Source: Survey data (2018)

3.7 Sample households crop production characteristics

All sample households were cultivated and grown Arabica coffee in the last ten years. Coffee is used as main source of income and base of their livelihoods. It is the most important crop in terms of cash earn and area coverage. On average Sample households' were planted 1.63 ha of coffee and obtained $554.87 \mathrm{~kg}$ per ha of clean coffee 
during 2017/18 cropping season. Next to coffee production, sample households were cultivated teff, wheat, maize and potato in terms of area coverage respectively. Sample households were used these crops as staple crops as well as income source (Table 8).

Table 8 sample households crop production in 2017/18 cropping season

\begin{tabular}{|c|c|c|c|c|c|}
\hline \multirow[t]{2}{*}{ Crop types } & \multirow[t]{2}{*}{ Observation } & \multicolumn{4}{|c|}{ Yield of different crops attained in $\mathrm{Kg}$} \\
\hline & & Minimum & Maximum & Mean & Std. Dev \\
\hline Wheat product & 31 & 400 & 2925 & 1759.68 & 586.8 \\
\hline Maize product & 74 & 400 & 6000 & 1745.94 & 995.99 \\
\hline Teff product & 80 & 200 & 3100 & 846.88 & 545.54 \\
\hline Potato product & 50 & 300 & 3600 & 1682 & 751.98 \\
\hline Coffee product & 114 & 100 & 2500 & 554.87 & 498.37 \\
\hline Coffee Area & 114 & 0.25 & 6 & 1.63 & 1.43 \\
\hline Teff Area & 80 & 0.25 & 5 & 1.56 & 1.16 \\
\hline Wheat Area & 31 & 0.25 & 5 & 1.02 & 1.02 \\
\hline Maize Area & 74 & 0.25 & 4 & 0.81 & 0.80 \\
\hline Potato Area & 50 & 0.25 & 2 & 0.45 & 0.37 \\
\hline
\end{tabular}

Source: Survey data (2018)

\subsection{Source of income in Wombera district}

Sample households have been adopting mixed farming system as well as agro forestry practices for the last ten years. Cultivated different staple and cash crops, rearing animals and planting different agro forestry's become common practices of the study area. They were used these crops, animals and forest types as source of food, income, shelter and wind break. As result, sample households of the study area were generated income from different income generating activities based on their knowledge, skills and capacities. They were generated income from selling of coffee, other crops, and livestock and off farming activities. The source of income generated was from selling of coffee, other crops like teff, maize, wheat and potato, livestock and off farm activities milling, petty trade and daily labor. Coffee was the main cash crops and have relative higher output price in the study area. They were generated income on average 26,441.70 Ethiopian Birr (ETB) from coffee, 13,921.61 ETB from other crops, 8,090.92ETB from livestock, 14,039.10 ETB from off farm activities annually. Income source of coffee shares $58.59 \%$ of the total annual income as well as coffee, other crops and livestock were dominant sources of incomes that share $94 \%$ of the sample household total annual income (Table 9).

Table 9. Sample Households' source of income in Wombera district

\begin{tabular}{cccccc} 
Income sources & Observation & Mean & Std. deviation & Minimum & Maximum \\
\hline Income of coffee & 114 & $26,441.70$ & $21,492.03$ & 4500 & 108,000 \\
Income of other crops & 96 & $13,921.61$ & $10,161.54$ & 500 & 55,500 \\
Income of Livestock & 60 & $8,090.92$ & $8,848.97$ & 430 & 52,000 \\
Income of Off farm & 22 & $14,039.10$ & $15,510.46$ & 600 & 48,000 \\
Total Annual income & 114 & $45,132.84$ & $31,300.54$ & 5,600 & 182,500
\end{tabular}

Source: Survey data (2018)

\subsection{Econometric analysis}

\subsubsection{Determinants of improve coffee variety adoption and Model adequacy}

The Tobit model was employed to identify factors that determined the rate and level of improved coffee varieties adoption. To identify the adoption rate and level of improved coffee varieties in North Western Ethiopia seventeen explanatory variables have been taken. Multi collinearity and heteroscedasticity problem among explanatory has an effect on model output estimation. Hence, before running of the Tobit model multi collinearity and heteroscedasticity problem among explanatory variables were checked using VIF and Breusch-pagan See Appendix I. The chi-square $(\chi 2)$ distribution was used as the measure of overall significance of a model in Tobit model estimation. The prob $>$ chi $2=0.0000$ is used to test the dependence of the adoption of improved coffee varieties on the selected independent variables in the model (the hypothesis that all coefficients are equal to zero is rejected at $1 \%$ significance level). The pseudo $\mathrm{R}^{2}(0.2277)$ which indicates that $22.77 \%$ of the improved coffee variety adoption is explained by the explanatory variables include by the model.

In the model prob $>$ chi $2=0.0000$ indicated that the Tobit model is adequate to determine the factors that influenced the adoption of improved coffee variety. Hence, the adoption decision of improved coffee varieties by households is best explained by the Tobit model. The results of the model show that out of the seventeen variables included in the model, six variables are correlated with probability of improved coffee varieties adoption and found to have statistically significant effects on the adoption of improved coffee varieties. The Tobit model outputs showed that Household head education level, participation on demonstration, allocated area for coffee production and income earned from coffee and access to extension service are variables that positively influencing the 
adoption improved coffee varieties whereas sex of Household head is a variable negatively influencing the adoption of improved coffee varieties in North western Ethiopia (Table 10).

Table 10 Determinants of improve coffee variety adoption and model adequacy

\begin{tabular}{|c|c|c|c|c|}
\hline Variables & Coefficient & Std. Err & T-value & $\mathbf{P}>\mathbf{T}$ \\
\hline HH sex & -0.96 & 0.44 & -2.22 & $\mathbf{0 . 0 3} * *$ \\
\hline HH Age & -0.01 & 0.02 & -0.87 & 0.39 \\
\hline HH Edu & 0.02 & 0.01 & 1.97 & $0.05 * *$ \\
\hline Model farmer & -0.17 & 0.27 & -0.63 & 0.53 \\
\hline Social contact & 0.38 & 0.37 & 1.05 & 0.30 \\
\hline Own land & 0.12 & 0.08 & 1.49 & 0.14 \\
\hline Access to save & -0.04 & 0.30 & -0.15 & 0.88 \\
\hline Training on coffee production & -0.14 & 0.26 & -0.53 & 0.59 \\
\hline Participation on Demo & 0.72 & 0.42 & 1.73 & $0.09 *$ \\
\hline Coffee area & 0.2 & 0.11 & 1.92 & $0.05 * *$ \\
\hline Coffee product & -4.26 & 0.00 & -0.01 & 0.99 \\
\hline Coffee income & $\mathbf{0 . 0 0}$ & 6.70 & 2.16 & $0.03 * *$ \\
\hline Other area & 0.09 & 0.08 & 1.16 & 0.25 \\
\hline Fertility & -0.13 & 0.21 & -0.58 & 0.56 \\
\hline Slope & 0.22 & 0.17 & 1.27 & 0.21 \\
\hline Access to extension & 1.65 & 0.56 & 2.93 & $0.00 * * *$ \\
\hline \# of extension contact & -0.01 & 0.01 & -0.89 & 0.38 \\
\hline \multirow[t]{4}{*}{ Const. } & -1.95 & 1.18 & -1.66 & 0.10 \\
\hline & \multicolumn{3}{|c|}{ Number of observation } & 114 \\
\hline & \multicolumn{3}{|c|}{ Pro $>$ Chi 2} & 0.000 \\
\hline & \multicolumn{3}{|c|}{ Pseudo R2 } & 0.2277 \\
\hline
\end{tabular}

Source: Survey data (2018)

$* * *, * *$, and $*$ are significant at $1 \%, 5 \%$, and $10 \%$ significance levels, respectively.

3.9.2 Determinants and marginal effect of improve coffee varieties adoption

The factors that affect the adoption of improved coffee varieties and its level of adoption were examined using the Tobit model. Seventeen explanatory variables were included in the model to examine the adoption rate and adoption level of improved coffee varieties under smallholder farmers in North Western Ethiopia. Six out of seventeen variables were statically significance and determined the adoption rate and adoption level of improved coffee varieties in North Western Ethiopia. The result of Tobit model showed that sex of household head, education level of household head, participation on demonstration, area allocated in ha for coffee production, income earned from sell of coffee and access to agricultural extension was determined the adoption rate and level of adoption of improved coffee varieties. These determinants that affected the adoption rate and level of adoption of improved coffee varieties were described as follow.

Sex of Household head: as the Tobit regression result showed sex of household head has negative and significant effect on the decision to adopt improved coffee varieties in North Western Ethiopia. Furthermore, female household heads were less efficient than male their counterparts. This is due to female household heads are less experienced on farming activities, too much occupied with home activities like child care, food preparing and water fetching and, less access to information on improved coffee varieties, lower labor endowment, less social network that less participated in meeting, demonstration and training. As result, female household heads are less likely to adopt improved coffee varieties than male headed farmers. The result of marginal effect revealed that being female-headed household, keeping other variables constant, reduced the adoption of improved coffee varieties by $25.30 \%, 23.89 \%$ and $39.66 \%$ of the adopter, non-adopter and the whole sample households respectively as compared to male-headed households. Female-headed households are uncommon and unrecognized in Ethiopian culture except widowed and divorced females. In such condition the cultural and socioeconomic factors affected their likelihood of adopting improved coffee varieties. The findings are familiar with (Dibaba and Goshu, 2019)

Educational level of household head: Education improves the capacity of smallholder agricultural producers in general and coffee producers in particular to easily understand and use different agricultural technologies particularly improved coffee varieties. Moreover, education improved access to information, managerial skills and to apply technologies with their appropriate agronomic practices. In this research, education has a positive and significant effect with the adoption of improved coffee varieties as it expected in hypothesis. Educational status of sample household head was showed statistically significance at 5\% and positive effect on decision to adopt improved coffee variety. Education was increased the probability of adopting improved coffee varieties by $4.1 \%$, $3.9 \%$ and $5.6 \%$ to the adopter, non-adopter and whole sample households respectively, by holding other variables 
constant. The findings are familiar with (Diro et al., 2017; Regasa Dibaba et al., 2018; Tewelemedhin, 2020)

Participation on demonstration: The participation on demonstration has positive effect and statically significance at $10 \%$ both on the adoption rate and level of adoption improve coffee varieties in North Western Ethiopia (Table 11). This implies that smallholder farmers who are participated on demonstration are more likely to adopt the improved coffee varieties. This is due to farmers more believed on practical exercising than theoretical. Moreover, participation on demonstration was increased the probability of adopting improved coffee varieties by $18.86,17.81$ and $29.28 \%$ on average for the adopter, non-adopter and whole respondent respectively, holding other variables constant. The finding is in line with (WelayTesfay, 2019)

Coffee income: The smallholder coffee producers who was earned more income from their coffee output sold encouraged enhancing their coffee production and productivity by adopting different coffee yield improvement strategies. Among different coffee yield improvement strategies, adopting improved coffee varieties is one option to smallholder farmers coffee producers to enhance their coffee output as well as income earned from the coffee sector. The income earned from coffee has positive and statistically significance at $5 \%$ on the adoption rate and level of adoption of improved coffee varieties (Table 11). This is due to the higher income earned from coffee output sold is motivate to adopt the new improved coffee varieties with the demand of earning higher income from the production of coffee in the future. Consequently coffee income earned was increased the probability of adopting improved coffee varieties by $37.80 \%, 35.70 \%$ and $51.40 \%$ on average for the adopter, non-adopter and whole respondents respectively, holding other variables constant. The findings are familiar with (Dibaba and Goshu, 2018)

Coffee area: It is obvious that allocating larger cultivated land for coffee production create an option to adopt improved coffee varieties thereby thinking to enhance productivity, production and earn profit from the coffee sector. Coffee area is the area allocated for coffee production which has positive and significant effect on adoption of improved coffee varieties. The positive effects of coffee area show that farmers with relatively allocated larger cultivated land for coffee decide to adopt improved coffee varieties than allocated smaller cultivated land for coffee production. Land As a basic production factor, the more farmers allocated larger land for coffee production, the more likely to adopt agricultural technologies particularly improved coffee varieties that could possibly increase coffee production. The result of marginal effect showed that as smallholder coffee producers increased area allocated for coffee production by one hectare, it enhanced the probability of adopting improved coffee varieties by $5.32 \%, 5.03 \%$ and $7.25 \%$ for the adopter, non-adopter and the whole sample respectively, holding other variables constant. The findings are familiar with (Dibaba and Goshu, 2018; Tewelemedhin, 2020)

Access to extension service: Access to extension service per year has positively and significantly related to adoption of improved coffee varieties, implying that farmers with more accessed to extension service is more likely to adopt improved coffee varieties than those with less accessed to extension service. Hence, Access to extension service by different agricultural extension service accessing approaches like demonstration, mass media, newspaper and experience sharing within district and outside the districts are assumed to be the potential force which accelerates the effective dissemination of adequate agricultural information to the farmers, thereby enhancing farmers' decision to adopt improved coffee varieties. The result of marginal effect indicate that as coffee producers accessed to extension service through different agricultural extension service accessing approaches, it enhanced the probability of adopting improved coffee varieties by $43.11 \%, 40.71 \%$ and $58.68 \%$ to adopter, nonadopter and the whole sample households of smallholder farmers respectively. Farmers who have accessed to agricultural extension service accessed have the ability to update themselves on the availability and arrival of improved coffee varieties and aware of its application techniques than those less accessed to agricultural extension services by agricultural extension service accessing approaches. The findings are familiar with (Diro et al., 2017; Dibaba and Goshu, 2018) 
Table 11 Determinants and marginal effect of improve coffee varieties adoption

\begin{tabular}{ccccccc}
\hline Explanatory variables & Coe. & Std. Err & $\mathbf{P}>|\mathbf{T}|$ & \multicolumn{3}{c}{ Marginal Effect } \\
& & & & Adopter & N/adopter & All sample \\
\hline HH sex & $\mathbf{- 0 . 9 6}$ & $\mathbf{0 . 4 4}$ & $\mathbf{0 . 0 3} * *$ & $-\mathbf{0 . 2 5 3 0}$ & $\mathbf{- 0 . 2 3 8 9}$ & $\mathbf{- 0 . 3 9 6 6}$ \\
HH Age & -0.01 & 0.02 & 0.39 & -0.0035 & -0.0033 & -0.0047 \\
HH Edu & $\mathbf{0 . 0 2}$ & $\mathbf{0 . 0 1}$ & $\mathbf{0 . 0 5 * *}$ & $\mathbf{0 . 0 4 1}$ & $\mathbf{0 . 0 3 9}$ & $\mathbf{0 . 0 5 6}$ \\
Model farmer & -0.17 & 0.27 & 0.53 & -0.0441 & -0.0416 & -0.0592 \\
Social contact & 0.38 & 0.37 & 0.30 & 0.1012 & 0.0956 & 0.1492 \\
Own land & 0.12 & 0.08 & 0.14 & 0.0308 & -0.0291 & 0.0419 \\
Access to save & -0.04 & 0.30 & 0.88 & -0.0113 & -0.0107 & -0.0154 \\
Training on coffee production & -0.14 & 0.26 & 0.59 & -0.0364 & -0.0344 & -0.0492 \\
Participation on Demo & $\mathbf{0 . 7 2}$ & $\mathbf{0 . 4 2}$ & $\mathbf{0 . 0 9 *}$ & $\mathbf{0 . 1 8 8 6}$ & $\mathbf{0 . 1 7 8 1}$ & $\mathbf{0 . 2 9 2 8}$ \\
Coffee area & $\mathbf{0 . 2}$ & $\mathbf{0 . 1 1}$ & $\mathbf{0 . 0 5} * *$ & $\mathbf{0 . 0 5 3 2}$ & $\mathbf{0 . 0 5 0 3}$ & $\mathbf{0 . 0 7 2 5}$ \\
Coffee product & -4.26 & 0.00 & 0.99 & -0.1110 & -0.1050 & -0.1520 \\
Coffee income & $\mathbf{0 . 0 0}$ & $\mathbf{6 . 7 0}$ & $\mathbf{0 . 0 3} * *$ & $\mathbf{0 . 3 7 8 0}$ & $\mathbf{0 . 3 5 7 0}$ & $\mathbf{0 . 5 1 4 0}$ \\
Other area & 0.09 & 0.08 & 0.25 & 0.0237 & 0.0224 & 0.0322 \\
Fertility & -0.13 & 0.21 & 0.56 & 0.0327 & -0.0309 & -0.0445 \\
Slope & 0.22 & 0.17 & 0.21 & 0.0584 & 0.0552 & 0.0795 \\
Access to extension & $\mathbf{1 . 6 5}$ & $\mathbf{0 . 5 6}$ & $\mathbf{0 . 0 0} * * *$ & $\mathbf{0 . 4 3 1 1}$ & $\mathbf{0 . 4 0 7 1}$ & $\mathbf{0 . 5 8 6 8}$ \\
\# of extension contact & -0.01 & 0.01 & 0.38 & -0.0021 & -0.0019 & -0.0028 \\
\hline
\end{tabular}

Source: Survey data (2018)

$* * *, * *$, and $*$ are significant at $1 \%, 5 \%$, and $10 \%$ significance levels, respectively.

\section{Summaries and Conclusion}

The study was conducted at Wombera district, Metekel Zone, Benshangul Gumuz National Regional state, in North Western Ethiopia, with the aim of determining the factors hinder and promote of improved coffee variety adoption rate and level of adoption under smallholder coffee producers'. The descriptive statistics result showed that adopter of sample households are relatively holds larger animal in TLU, produced higher coffee output, earned higher income from coffee, older, more social networked, obtained training on new coffee and other crop varieties, access to financial and agricultural service, complete higher class, owned larger cultivated land and allocated larger cultivated land for coffee than non-adopters whereas non-adopters were had larger family size, adult equivalent and man equivalent than their counterparts. It also indicated that adoption rate and level of adoption of improved coffee varieties is $29.82 \%$ and $40.67 \%$ in North western Ethiopia respectively.

The result of Tobit regression revealed that sex of household head, educational status of household head, participation on demonstration, area allocated for coffee production, income earned from sell of coffee and access to agricultural extension service was the main factors that determined improved coffee varieties adoption rate and levels in the study area. Educational status of household head, participation on demonstration, area allocated for coffee production, income earned from sell of coffee and access to agricultural extension services have statistically significance and positive effect whereas sex of household head has statistically significance and negative effect on the improve coffee variety adoption decision. IN general, adoptions of improved coffee varieties are means of income improvement and ensuring food security of smallholder farmers. Therefore, governmental authorities and NGOs should be focus on expanding of education to all smallholder farmers through formal and informal educational approach, support demonstration of new technologies at smallholder farmers level, access to improved coffee varieties through agricultural extension service programs which improved the rate and level of improved coffee varieties adoption as well as improved the productivity and production of coffee sector. It also focused on the expanding and disseminating of these improved coffee varieties over the coffee pro agro-ecologies of the countries.

\section{Acknowledgement}

I gratefully acknowledged to Ethiopian Institute of Agriculture Research for financial and logistics support to conduct this research as well i want to thanks to those researchers who were provided support and facilitation during data collection and data entry.

\section{Reference}

CSA(Centeral Statistics Agency), 2018. Area and production of major crops Centeral Statistics, Government of Ethiopia.

Dibaba, R., Goshu, D., 2018. Impact Of High Yielding Wheat Varieties On Farm Income Of Smallholder Farmers In Ethiopia. Review of Agricultural and Applied Economics (RAAE) 21, 103.

Dibaba, R., Goshu, D., 2019. Determinants of High Yielding Wheat Varieties Adoption by Small-Holder Farmers 
in Ethiopia. Journal of Natural Sciences Research Vol.9, No.12, 2019.

Diro, S., Asfaw, E., Erko, B., Anteneh, M., 2017. Factors affecting adoption and degree of adoption of soya bean in Ilu-Ababora Zone; Southwestern Ethiopia. Agricultural Science Research Journal 7, 15-26.

Fantaye, W.G., 2019. Trend Analysis of Coffee (Coffea Arabica L.) Productivity, Area of Production and Numbers of Holders in Ethiopia. Journal of Natural Sciences Research Vol.9, No.15, 2019, 1-6.

Fitsum, M., 2016. Analysis of the factors affecting adoption of soybean production technology in Pawe District, Metekele Zone of Benshangul Gumuz Regional State, Ethiopia. World Scientific News 53, 122-137.

Kedir, M., Bekele, A., Zemedu, L., 2017. Adoption and Impact of Improved Soybean (Belessa-95) Variety among Smallholder Farmers in Bambasi Woreda, Benishangul Gumuz Regional State. Haramaya University.

Maddala, G.S., 1986. Limited-dependent and qualitative variables in econometrics. Cambridge university press.

Misganaw, A.A., Bezabih; Efrem Asfaw, 2015. Adoption and Impact of Coffee Production Technologies in the Case of Western Ethiopia. Journal of Biology, Agriculture and Healthcare Vol.5, No.23, 2015, 65-72.

Moti, J., Chilot, Y., Menale, K., Hugo, d.G., Bekele, S., 2013. Knowledge, Adoption and Use Intensity of Improved Maize Technologies in Ethiopia 4th International Conference of the African Association of Agricultural Economists, 1-29.

Regasa Dibaba, Afework Hagos, Chilot Yirga, Habite, E., 2018. Determinants of Improved Teff Varieties Adoption and Its Impact on Productivity: The Case of Non-Traditional Teff Growing Areas of Western Ethiopia. Journal of Natural Sciences Research Vol.8, No.22, 2018, 55-67.

Samuel, D.S., Assef; Beza, Erko, 2016. Trends and Determinants of Coffee Commercialization among Smallholder Farmers in Southwest Ethiopia: Jimma Zone Coffee Potential Districts. World Journal of Agricultural Sciences 12 (2), 2016, 138-148.

Tewelemedhin, W.T., 2020. Impact of improved coffee variety adoption on enhancing annual income of smallholder farmers in North Western Ethiopia.

Tobin, J., 1958. Estimation of relationships for limited dependent variables. Econometrica: journal of the Econometric Society, 24-36.

WDAO(Wombera District Agriculture Officee), 2018. Annual Agricultural activities performance report.

Welay, T., Desalegn, T., 2019. Impact of Improved Soybean Variety on Enhancing Productivityand Gross Farm Income of Smallholder Farmers in North Western Ethiopia. Journal of Natural Sciences Research Vol.9, No.15, 2019, 25-39.

WelayTesfay, 2019. Analyses of Factors Determine the Rate and Level of Improved Soybean Variety Adoption Under Smallholder Farmers in North Western Ethiopia. Journal of Economics and Sustainable Development Vol.10, No.23, 2019.

Yemane, T., 1967. Statistics an Introductory Analysis, 2nd Ed., New York: Harper and Row.

Zewdu, Y., 2016. Explaining the Determinants of Ethiopia's Coffee Export Performance and Potential.Ethiopian Coffee Exporters ${ }^{\text {ee }}$ Association.

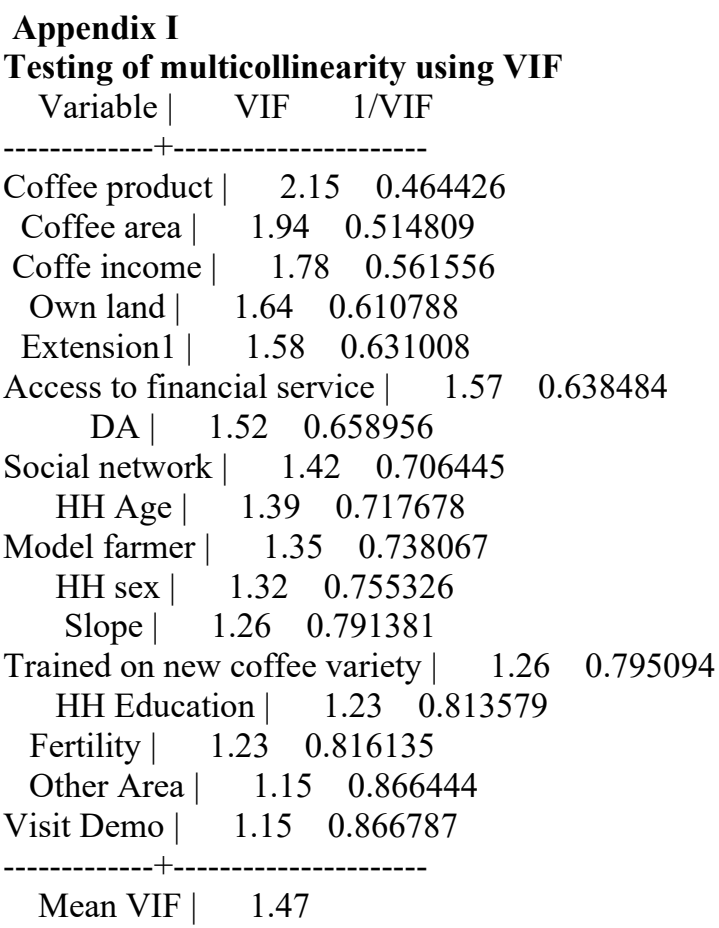


Test heteroscedasticity using het test

Breusch-Pagan / Cook-Weisberg test for heteroscedasticity

Ho: Constant variance

Variables: fitted values of Gr_improved

$\operatorname{chi} 2(1)=2.81$

Prob $>$ chi $2=0.10$ 